\title{
The Influence of Syncretism on the Ethnic Denominations of African Religion in the Benue Valley of Nigeria: The Tiv in Perspective
}

\author{
Andrew Philips Adega (Corresponding author) \\ Department of Religion and Cultural Studies, Benue State University \\ Makurdi, Nigeria
}

Tel: 0-805-522-0744; 0-703-128-0203Ｅ-Mail: aadega@bsum.edu.ng;

andy4everyoung@gmail.com

Received: January 7, 2022 Accepted: February 14, 2022 Published: February 20, 2022

doi:10.5296/ijch.v9i1.19566 URL: https://doi.org/10.5296/ijch.v9i1.19566

\begin{abstract}
In a competitive world where everyone and every system is trying to outdo one another to create a sense of relevance, the tendency of not being satisfied with a particular way in which something has been done over the years is often to copy or emulate what the other is doing. Religion is not free from this tendency; and this creates a situation where some elements or a reasonable chunk of ideas are copied and fussed into a religious tradition from one or more opposing or distinct religious groups. The idea of fusion in religious circles is known as religious syncretism. The paper is motivated by the seemingly fusion of Christian and Islamic patterns of beliefs in the Ethnic Denominations of African Religion in the Benue Valley of Nigeria. The paper adopts the Phenomenological and Analytic Methods. In the area of data collection, two main methods: the primary and secondary methods of data collection have been employed. In the primary source of data collection, observation and oral interview methods were used. On the other hand, the secondary sources of data collection employed the use of textbooks, journal articles, newspaper/magazine articles and e-sources. The paper discovered that syncretism has been a reoccurring decimal in religious circles. Thus, a particular religion copies and infuses into its system some distinct ideas from a different religious tradition. The Ethnic Denominations of African Religion in the Benue Valley particularly Tiv Religion has been greatly influenced by syncretism. Tiv Religion has adopted and fused certain beliefs from Christianity and Islam in such areas as prayers, use of prayer beads, holy water and worship patterns. It is the view of this paper that if this trend goes unchecked, the Ethnic Denominations of African Religion in the Benue Valley especially Tiv
\end{abstract}


Religion would wholly syncretize itself in the garb of foreign religious traditions. The paper suggests that the adherents of Tiv Religion should continue with their unique way of prayer and worship as prescribed in Tiv Religion instead of syncretizing different religious practices with the prospects of losing their entire culture to foreign ones. The uniqueness of Tiv Religion and culture must be protected from going extinct. The practitioners of the Ethnic Denominations of African Religion in the Benue Valley must note the fact that God listens to those who worship him through different cultural platforms. Therefore, one does not need to adopt foreign ideas to be relevant or heard by God. This is what makes God, God.

Keywords: religious syncretism, African religion, Tiv, ethnic denominations

\section{Introduction}

In the history of societies across the globe, it has come to the general realization that where two or more systems and cultures co-habit or exist side by side, the tendency is for one of the cultures or systems to copy, fuse or imbibe the values of the other into its original cultural forms and values. Sometimes this may be on large scale while in some instances this may be on a minimal scale. In religious circles, the fusion of ideas from one religious' tradition into another is referred to as religious syncretism.

Syncretism is the combination of different forms of beliefs or practices. The Ethnic Denominations of African Religion in the Benue Valley of Nigeria; particularly the Tiv ethnic denomination has in recent times clearly shown the influence of syncretism in its worship patterns, prayers and other forms of religious rituals from Christianity and Islam into its original ideas of religious beliefs and practices which were on ground long before any other form of civilisation.

It is a normal occurrence that where two or more systems/cultures meet; the dominant system/culture overwhelms and tends to swallow up the weaker system(s). This is the foreseeable danger posed to Tiv Ethnic Denomination of African Religion by Christianity and Islam. Thus, if care is not taken, the Ethnic Denominations of African Religion in the Benue valley particularly Tiv Religion will end up being swallowed up by the infusion of ideas from foreign religious traditions such as Christianity and Islam.

Therefore, having been so over-blotted with infusions from foreign religious ideas, the ethnic denominations of African religion in the Benue valley would have lost their originality and identity. It is with the above problem in mind that the paper, the influence of syncretism on the Ethnic Denominations of African Religion in the Benue valley: The Tiv Experience has been written. The paper is divided into major and sub-themes for clarity and better understanding. These include: the explication of terms/concepts, the meaning of syncretism as well as the influence of syncretism on the ethnic denomination of African religion in the Benue Valley, the Tiv experience. The causes and effects of syncretism will also be examined. Some valuable suggestions will be made and a conclusion drawn. 


\section{Review of Related Literature}

\subsection{Explication of Terms/Concepts}

The underlisted words, terms and concepts as used in this paper have the following meanings:

Ethnic: This connotes a group of people having common racial, national, religious or cultural origins.

Denomination: This is a branch of a religious sect.

African Religion: Also known as African Traditional Religion (ATR), it is the Indigenous Religion of the Africans. It is the aboriginal religious traditions of the Africans sequel to the advent of the foreign religious imports of Judeo-western European Christianity and the Arabo-Barber traditions of Arabia. As Kanu (2015:5) explicitly explained, African Religion as a concept can be employed in two complementary senses. Loosely, it encompasses all African beliefs and practices that are considered religious but neither Christian nor Islamic.

Kanu (2015:4) therefore defined African religion as the indigenous practices and beliefs, facts, customs, often handed down from generation to generation, unwritten or written. The religion as a matter of fact is largely unwritten prior to the documentation being currently made by scholars rather than the practitioners themselves. A good number of the scholars of African Religion are in fact practicing Christians, ministers and or theologians including pioneering scholars like Mbiti and Idowu. This trend is attributed to the absence of literacy abinitio on the African continent. African Religion combines the idea of the past, the present and the future. It is still being practiced today by African women and men of goodwill even though its adherents have significantly been reduced due to the influence of Islam and Christianity.

Though, African religion is not a religion of the books nor is it a revealed religion; it is nevertheless "written" everywhere for those who care to see and read. Furthermore, Awolalu (1979:26-29) stated that African Religion though not written is transmitted through various sources including: myths/legends, folktales, songs, proverbs, songs, names and oaths. Other sources of African Religion are: sacred specialists, sacred spaces, objects and symbols.

Therefore, Ethnic Denominations of African Religion in the Benue valley of Nigeria as the name suggests refers to the branches/sects of African Religion in the Benue valley of Nigeria; especially the Tiv denomination which is in focus in this paper. The area Benue valley of Nigeria is variously referred to as the Middle Belt region, North Central Nigeria, or simply Central Nigeria.

As Adega (2013:36) pointed out, the geographical location known as the lower Benue region is located in the lower Basin of the river Benue and all the people/ethnic nationalities that live within the area. In the present Composition of the geographical spread of Nigeria, the Benue Valley comprises the States of Benue, Plateau, Nasarawa, Kogi, Kwara, Niger and Abuja- the Federal Capital Territory (FCT).

Some of the ethnic nationalities in the Benue valley of Nigeria include but limited to the following: Tiv, Idoma, Igede, Etulo, Ufia, Arago, Eggon, Koro, Agatu, Ngas, Birom, 
Mupun and Mwaghavul. Others are Igala, Igbira, Bassa, Nupe, Gbagyi etc. These ethnic nationalities represent the ethnic denominations of African Religion in the Benue valley of Nigeria.

Before the advent of Christianity and Islam, the ethnic nationalities of the Benue valley were deeply religious and were engaged in the practice of different versions - denominations of African religion as best known to them. For instance, the Tiv worshipped Aondo (Supreme Being), Ujijingi (spirits), Akombo (ritualistic performances) and tsav (witchcraft). On the other hand, the Idoma worshipped Owoicho - Omanchala (God almighty) while the Igede worshipped Ohe (Supreme Being) and other spirits including Ajenu, Apuruja and Oyita. The ethnic nationalities of the Benue Valley as a matter of fact were generally a deeply religious people by nature (Adega 2013:36).

Syncretism: Syncretism refers to the combination of different forms of beliefs or practices. It also refers to the amalgamation or attempted amalgamation of different religions, cultures, or schools of thought. In the words of Mokotso (2015:159), syncretism as used in religious studies or social sciences, that is, in the fields of Phenomenological or Comparative Studies or objective, scientific study of religions implies the situation when "the facts of a fusion of beliefs or practices is reported". Linguistically, the Oxford Pocket Dictionary of Current English viewed that syncretism entails the merging of different inflectional varieties of a word during the development of a language.

Nyuyki and Van Niekerk (2016:388) citing Tipper said syncretism is the union of two opposite forces, beliefs or tenets so that the united form is a new thing, neither one, or the other. This implies the mixing of elements of two religious systems to the point where at least one, if not both of the systems losses its basic structure and identity. The Wikipedia posits that religious syncretism exhibits blending of two or more religious belief systems into a new system or the incorporation into a religious tradition of beliefs from unrelated traditions. It is contrasted by the idea of multiple religious belonging and polytheism, respectively (https://en.wikipedia.org/wiki/religioius-syncretism...).

For Encyclopedia.com, syncretism is a process whereby two or more independent cultural systems or elements thereof, conjoin to form a new and distinct system. It further explained that this scenario is among the most important factors in the evolution of culture in general, but especially in the history of religion. It noted that all the so-called world religions i.e Christianity, Islam, Judaism, Hinduism, Buddhism and Confucianism, are to a large extent syncretistic. However, the process occurs whenever previously independent belief systems come into sustained contact, no matter what their respective levels of sophistication may be (https://www.encyclopedia.com...)

On the etymology of the word syncretism, Ezenweke and Kanu (2012:73) inferred that it comes from the Greek word synkretismos. Its origin they maintained, is the custom of the people who lived in the Island of ancient Crete who were fond of fighting themselves, but when enemies from outside attacked, they combined force with each other to combat their foreign enemy. The Cretans called this practice sykretismos, which comes from the verb meaning "to combine". This togetherness among things that have not been, and perhaps 
should not be together gives the term its energy and openness to controversy, syncretism in religion thus implies crossed doctrinal, liturgical, and institutional borders. Sanou (nd: 132) credits Plutarch as the first person to have used the word syncretism.

Similarly, the concept is also employed to refer to the uniting of quarrelling brothers in the face of common enemies. On a general term therefore, syncretism would refer to the attempt to unite together those elements which do not agree. Sanou (nd :132) in examining the factors for religious syncretism proffered that amongst other reasons:

i. A growing acceptance of religious pluralism in which the word has become a religiously plural place. According to him, people of diverse ethnic origins and many dissimilar religious commitments live and share public life together. This globalisation he emphasised has put major world religions within the reach of almost everyone in the world today. Worldwide migration patterns, international travel and trade, progress in communications technology and international media activities have introduced people to nearly all religions.

On their part, Ezenkweke and Kanu identified (79-80) the factors or causes of religious syncretism to include:

ii. Geographical, economic and linguistic factors: These, they explained facilitated syncretism in the sense that, cosmopolitan cities or business nerve centres could favour cultural contacts, language dissemination and the interchange of gods.

iii. Religious tolerance could also trigger syncretism in the sense that, syncretism becomes an effort to plug all the gaps in a given religion.

iv. The innovations in Christianity often said not to provide for some of the functions the traditional values perform. This is because the gospel displaces them without replacement. This is the major reason why the African indigenous church movements are growing by geometrical proportions. These indigenous churches provide traditional needs for spontaneous prayer, exorcism and faith healing lacking in established churches.

\subsection{Syncretism in the World Religions}

Encyclopedia.com outlines the following sequence and pattern of syncretism in the world religions as follows:

\section{Christianity}

It is probably the most syncretistic of all the world religions. While Christianity is rooted in Judaism, its surprisingly came to absorb elements of Zoroastrianism; the ancient Iranian religion; it adopted some elements also of Pharoanic Egyptian religion, the religion of ancient Mesopotamia just as it did of a number of Greco-Roman cults, which were themselves highly syncretistic. The Zoroastrian impact for instance which was already in post exilic Judaism, was profound indeed. A good example here is the intense Christian (and late Judaism) emphasis on a constant struggle between good and evil, which was the essence of the religion founded by Iranian prophet Zoroaster (Zarathrustra, c.630-550 BCE). Similarly, the fully evolved figure of the Hebrew concept of Lucifer, the "fallen angel", the Zoroastrian figure 
Angra Mainyu (Ahriman), who is the evil opponent of Ahura Maza (Ormazd), the "wise lord" and the embodiment of light, truth and goodness (https://encyclopedia.com).

Furthermore, the late Zoroastrian texts tell of a final conflict between Ahura Mazda and Angra Mainyu, in which a messiah-like figure will appear and lead the forces of good. This episode is dramatically reflected in a number of Judeo-Christian apocalyptic texts, from the book of Daniel to the book of Revelation. However, the important thing to note here is that neither Angra Mainyu nor Lucifer is identical to Satan. Instead, the Judeo-Christian figure is a syncretism of the two otherwise distinct evil entities.

Not only that, precursors to the importance of the resurrection of Jesus for Christianity were resurrected Egyptian god-Osiris, as well as the Mesopotamian deity, Dummuzi, who was rescued from the land of the dead by his divine lover Inanna. The Egyptian cult of the goddess Isis, sister-wife of Osiris and mother of the god Horus who together with Astarte and other Near Eastern goddesses, influenced the rise of the medieval cult of the Virgin Mary. In addition to those, the Isis cult considerably affected Christian rituals. For instance, the Sistrum, a tinkling rattle that was shaken during ceremonies honouring the goddess is the source of the bell that is rung several points in a Roman Catholic mass (httsp://www.encyclopedia.com...).

In another aspect, numerous Greco-Roman spiritual cults additionally impacted Christianity. A suitable instance may be visible in the dove which is a great image of the goddess, Aphrodite and her Roman counterpart, Venus which have become an image of the Holy Ghost, and the god Apollo turned into every now and then equated with Christ.

\section{Islam}

Islam also has drawn extensively from older religions including Christianity and Zoroastrianism most especially after the Muslim conquest of Iran in 641 C.E. The foremost Muslim demon, Iblis, is evidently similar to Angra Mainyu, and Islam also holds that there will be a final battle, Armageddon-like between the forces of good and evil. McDowell and Gilchrist (1983) also reported that, Islam adopted several rituals from Christianity including the prayer beads.

\section{Hinduism}

Classical and modern Hinduism are characterised as a majestic syncretism between the indigenous Dravidian belief systems of northern India, as reflected in the artifacts of Indus valley civilisation and those carried into India in the Middle of the Second Millennium BCE by the Aryans; whose beliefs were a variant of those carried by Indo-European speakers across Eurasia from India to Western Europe. Instances can be drawn from the major Hindu god Shira, the third member of the trinity that includes: Brahma and Vishnu. Shiva is often referred to as "the Lord of Beasts". An Indus valley stamp seal found at Mohenjo Daro dating from C.1800 BCE indicates a god seated in the lotus position and surrounded by animals. This supposes that the god in question, reflects a syncretism of the ancient Dravidian and Aryan religions. Similarly, the copiously evolved Hindu status system involves a unification of the Aryan tripartite social class system, which they shared with other ancient 
Indo-European speaking communities. The aboriginal emphasis on occupation groups is clearly evident in the physical layout of the chief Indus Valley cities: Mahenjo Daro and Harappa.

Religious syncretism seems to resist boundaries as it can be found in the Caribbean primarily as a result of the slave trade which a host of West African religious beliefs were transferred to Cuba, Haiti, Brazil and other Caribbean Islands between the $17^{\text {th }}$ and $18^{\text {th }}$ centuries. These religious tenets were intermixed with the Roman Catholicism of the slave masters and plantation owners and this marriage of convenience gave birth to syncretistic religions, the most important being Santeria and Voodoo (vodou/vodin) (httsp://www.encyclopedia.com).

Santeria acquired shape in Cuba principally and it imitates for the most part, the beliefs of the Yoruba people who dominantly live in Nigeria now. The focus of the Yoruba belief system as in among other West Africans is upon a pantheon of deities called Orishas. It is to be noted however, that, these figures in Santeria are often linked i.e syncretised with Catholic Saints. For example, Chango (Sango), a male god of thunder, lightening and fire is identified with St. Barbara, a devout young woman who lived in the $4^{\text {th }}$ century C.E and who was beheaded by her father for refusing to give up her Christian faith and marry according to his wishes. As she was being beheaded, her father was struck by lightning, which gave rise to the legend that St. Barbara had power over lightning bolts. Even though Chango is a masculine Orisha, the similarities between this legend and the Yoruba traditions about him, led to the syncretism in question.

Relatedly, Haitian voodoo is similar to Santeria in many ways as can be seen in its African heritage and when it comes to syncretism. Just as in Santeria in Voodooism, the West African deities, chiefly from Benin and Dahomey, are called Loa and are usually identified with Roman Catholic Saints. For instance, the serpent Loa, Damballah is often identified with St. Patrick, which draws on the legend that the latter drove the snakes out of Ireland.

Also, Houngan, or voodoo priests, have long since adopted elements of Roman Catholicism in voodoo rituals, such as the use of candles, bells, crosses, baptism, as well as making the sign of the cross. These Christian elements are blended and intertwined with such African religious practices as drumming, dancing, ancestor veneration and spirit possession amongst other ritualistic practices and observances (www.encylopedia.com)

The preceding analysis from major world religious traditions has clearly shown that no one religious tradition is original in itself to the core as certain elements have been drawn from other distinct and sometimes, opposite religious traditions into others to form new systems. The itinerary has shown that most often, a new religious tradition adopts or amalgamate ideas from an older one; an already existing religious traditions and similarly syncretise ideas from another religious traditions which has already been in practice but which it is just coming into contact with - as in the case of African religion adopting from Islam and Christianity. 


\section{Results and Discussions}

3.1 The Influence of Syncretism in the Ethnic Denominations of African Religion in the Benue Valley of Nigeria: The Tiv Experience

The discussion in this paper has shown that syncretism is not a new phenomenon in religious circles as different religious traditions have often amalgamated or fused some religious practices into its/their belief systems thus having a blend of ideas. The phenomenon of the influence of religious syncretism has firmly crept into the Ethnic Denominations of African Religion in the Benue valley particularly the Tiv ethnic denomination.

The origin of syncretism in Tiv Religion of foreign elements may not be precisely known; however, it is thought to have begun around 1912 with the emergence of the Ijov (singular) or Azov/Adzov (plural) in Tivland. As Adega (2019:294-295) noted, as a religious movement, the ijov emerged in 1912 due to the over bearing influence of the Mbatsav (witches) and their perpetration evil in Tiv society. The initial aim of the Ijov/Azov was to attack and possibly destroy witches; they later spread their tentacles to other religious roles including healing.

Adega (2019:298) further maintained that as a religious institution, the Ijov/Azov perform vital functions in Tiv society which religion is supposed to perform i.e spirit possession, exorcism and spiritual attack on witches and witchcraft practices. The succeeding discussion shall be focused on the influence of syncretism on the Ethnic Denominations of African Religion in the Benue Valley particularly, Tiv religion.

Prayer: In the words of Gbenda (2006:65), prayer is a universal phenomenon associated with almost all religions with a long history of practice and development throughout the ages. It is based on the conviction of the supplicant that there exists the transcendent being who is capable of influencing all spheres of life and who has a relationship with man. Therefore, to pray entail speaking to God in order to ask for help or give thanks (Adega 2019:180).

The act of prayer in the pattern of Christianity has influenced Tiv Religion. This is most noticeable among the Ijov/azov spirit possession movement or cults. Prayers take place during Ijov religious worship sessions on Fridays. Members pray in the triune name of God, the father, son and Holy Spirit.

Members of the azov cult also fast and perform healing sessions during which prayers and denunciation of evil embodied in witchcraft come under severe attacks (Adega 2019). A first timer to the praise and worship session of the azov worship session would mistake the scenario for a Christian/Pentecostal worship session chracterised by rowdiness, frenzy atmosphere and spirit possession. Apart from the azov, other category of the ethnic denominations of African religion such as healers, diviners, medicine men and women pray to seek the face of Aondo-God before embarking on their various trades.

Worship patterns: To worship is to honour and adore a deity. Okeke, Ibenwa and Okeke (2017:6) citing Hastings stated that worship comprises all modes of giving expression to the various feelings towards the divine power, feeling of awe, reverence, obligation, depreciation, gratitude, hope, etc. The Tiv ethnic denomination of African religion in the Benue valley 


\section{Mll Macrothink}

embodied in the ijov/azov religious movements/cults do worship in the manner of the Christian religion characterise with singing, dancing, drumming, and clapping which often culminates in spirit possession and ecstatism of the female members. Adega (2019) observed that it is during this period of worship and frenzy that healing remedies are received from the Azov (spirits) from which these groups are named for different ailments. Members dress in white apparels like the Aladura white garment church members. Fridays are dedicated for public worship. Offertories are made during worship and members of the worship community also give alms to less privileged members of the society.

Use of Islamic/Christian Prayer beads: A prayer bead is a string of small balls making up the rosary or paternoster (Christians) and the chasbi/chalbi (Muslim). The prayer beads are used in counting the prayer said. In the Tiv ethnic denomination of African Religion in the Benue valley; the use of the rosary, paternoster or chasbi is most evidently used by the $m b a$ kpehen asor (diviners). Diviners who employ the services of the Christian/Muslim prayer beads do so during consultation of clients. The diviners use the paternoster to decode and obtain secret or mysterious knowledge from the supersensible or spiritual forces. Members of the Adzov spirit possession movements/cults also use the prayer beads; particularly the Christian rosary for prayers. Wearing the rosary on their necks, they could pass for catholic novitiates and catechumen (Adega 2019:290).

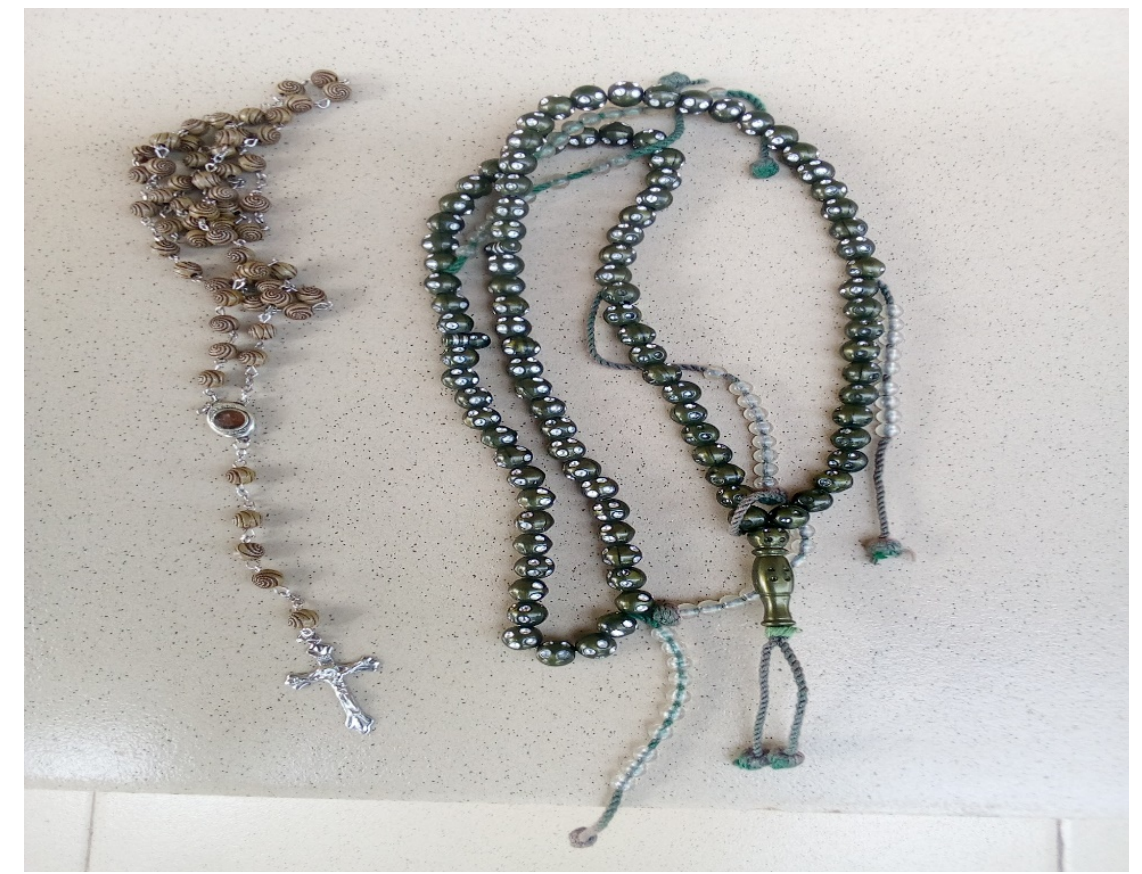

Plate 1. The Christian and Muslim prayer beads used by some ethnic denominations of African Religion in the Benue valley

Use of Islamic/Christian Sacred texts: The Islamic and Christian sacred texts of the Holy Qur'an and the Holy Bible are employed by members of the Tiv ethnic denominations of African religion in the Benue valley. The mba kpehen ishor (diviners) use it as a medium of ishor ikpehen (divination). When consulted by their clients over an issue for instance, a 


\section{Macrothink}

missing item, they open the bible to get revelation on how best to tackle and solve the problem. Most often, the first passage of the Bible/Qur'an that is opened becomes the source of solution to the problem. This implies that the diviner who thus uses the Islamic/Christian sacred text does not have particular passages of choice beforehand.

In trying to identify the culprit in a theft incidence, a key with pronged edges is inserted into the book of Psalms for those who use the bible. This is tied with nylon with the edges of the key protruding/projecting outside to make it easier to be held by the index fingers. The suspected one on either side holds/supports one edge of the key and after some incantations, they each take the oath stating "if I am responsible for the missing item, money, etc let the key turn". If the suspect is innocent, the key does not turn with the bible. However, if the person is responsible for the theft or missing item(s); the key beings to turn or swivel.

Odili (2017:161) also alluded to the use of the Holy Bible for divinatory purposes by African traditionalists including the African founded churches such as the Zion churches. On the other hand, members of the ijov/azov religious movements/cults also find the Christian Holy Bible useful and have thus syncretized it into the worship and ritual observance. Adega (2019:290) pointed out that at ijov/azov religious worship sessions; readings from the Holy Bible precede worship and healing of sick clienteles. Following the reading of the Holy Bible, a sermon is preached by the Ijov priest. The sermons mostly aim at denouncing Satan, evil, witchcraft, and immoral conducts in the community and society at large.

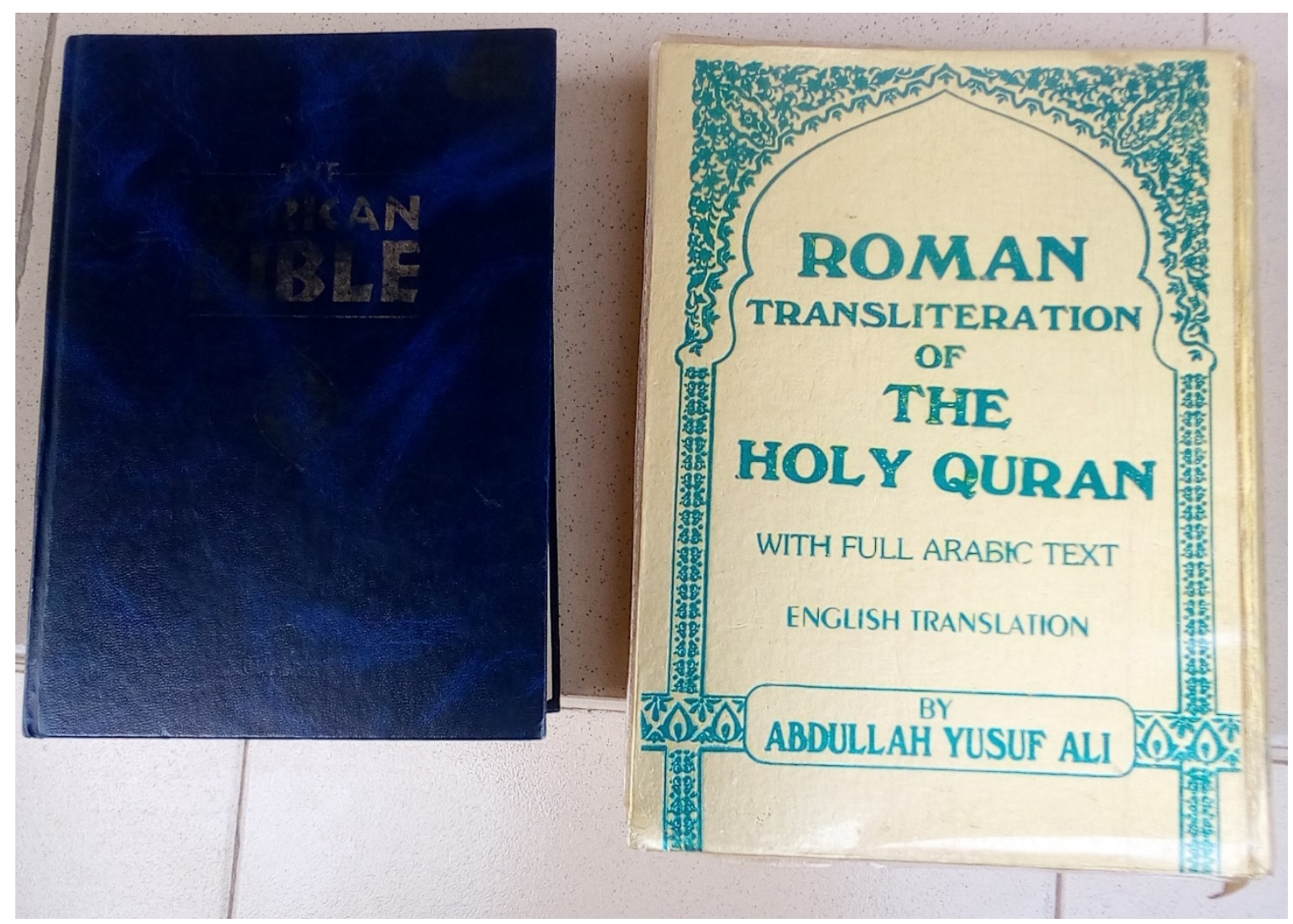

Plate 2. The Islamic and Christian sacred texts of the Holy Qur'an and the Holy Bible used by members of the Tiv ethnic denominations of African religion in the Benue valley 


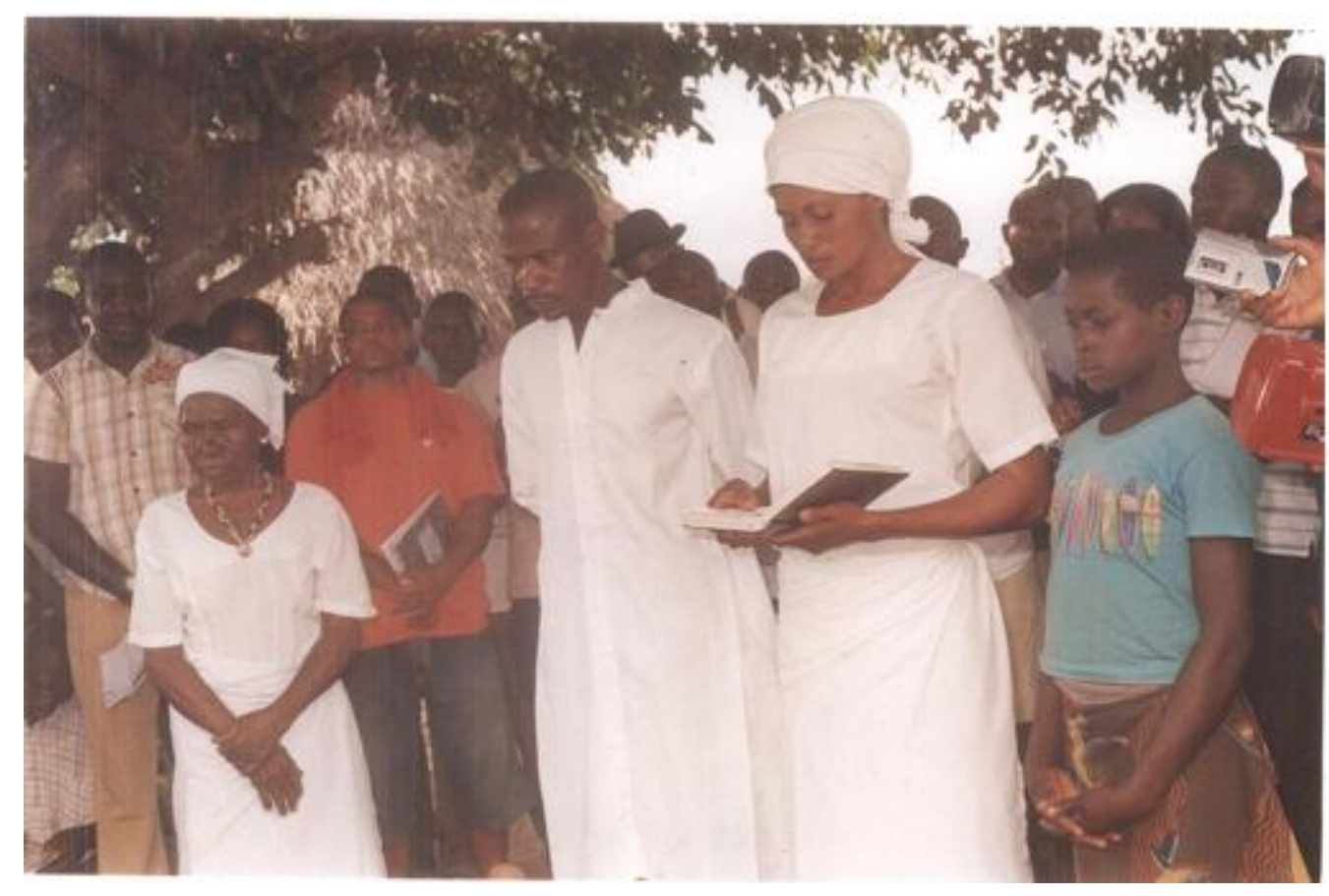

Plate 3. Mrs Mwuese Tyochir Priestess of Ijov Aondo in ceremonial white apparels at Akpagher- Mbatiav, Gboko local government area reads a passage from the Holy Bible during a worship and healing session

Source: An African Perspective on Phenomenology of Religion, 2019:269.

Holy Water: Also, sanctified water. It is used by members of the Tiv ethnic denomination of African religion in the Benue Valley. Commenting on the importance of water in the services of religion, Adega (2014:141) stated that as a ritual ingredient in religion, water is used for baptism and consecration of host in Christianity (cf. 2Kgs 2:19-22; Ezek. 36:25). Water is used in Islam for the purposes of ablution which is a ritual cleansing for the obligatory prayers (salat).

In the Tiv ethnic denomination of African religion in the Benue valley; water is used by $m b a$ kpehen isor (diviners), azov spirit possession cult members, medicine men/women and healers. Adega (2014) further elaborated that in Tiv religion, water is used in the performance of several ritual such as ifan i gberen/hamber) (removal curses), atar a tondon/ihira igberen (ritual for good luck). He enthused that mngerem (water) is also used in the preparation of medicines i.e boiling herbs and the grinding of herbal pastes for application on incisions and that water is used in the various stages of kwagh soron (healing) rituals.

Mba yilan ura (rain makers) among the Tiv similarly use water in the performance of their trade. Seeing the diverse uses of water and its application in various ritual ceremonies, Higgins (1965:552) opined that water is a purifying agent and has so gained importance in ritual cleansings and has become a symbol of inward purification. This explains why members of the ethnic denomination of African religion in the Benue valley bless and keep 
sanctified water for their use. Sometimes, these traditionalists even send people to collect the water blessed by a priest to enhance the efficacy of their rituals - this without the knowledge of the Christian priest.

On the other hand, the ijov/azov spirit possession cult uses water for blessing members of their congregation. This takes place during worship, payers and healing session. This is performed by the ijov priest. Added to the holy water is tulari (scent/perfume) i.e Binta el sudan which aims at attracting the spirits in order to tap from their secret knowledge and gain their blessings (Adega 2019). Tiv medicine men and women also use Alfhares, 777 perfumes and incense in the preparation of protective charms. Subscribing to the use of sanctified water for blessings, prayers and healing, Odili (2017:155-156) averred that sanctified water is significant for therapeutic and prophylactic functions, and it assumes a potent force and symbol for purification and for chasing away malevolent spirits. He thus, itemized the symbolic value of water to include:

(i) It cleanses and washes away dirt

(ii) Fills everything signifying the immanence

(iii) The individual needs water to survive physically just as God is needed for spiritual survival. Sanctified water is therefore used at blessings, dedications, exorcism and burials (Odili 2017:156).

On a general note commenting on the use of sanctified or holy water by Africans and practitioners of the denominations of African religion in the Benue valley particularly the Tiv version; Ugwu (2014:38) remarked that:

Today you can experience the use of this water hung on economic trees to prevent pilfering and tempering by passersby. Sometimes because of the syncretic nature of Africans, they obtain holy water and stickers from some Christian adoration ministries and stick them to their economic trees and sometimes also hang bottles of blessed Goya oil and water on these trees.

In Tivland, the aforementioned items: stickers, sacramental, holy water, Goya oil etc are purchased for those that can be purchased with the exception of holy water at weekly/monthly crusades by catholic priests such as Revd. Fr. Hycinth Alia, Revd. Fr. Matthew Dzer, Revd. Fr. Emmanuel Asue, Revd. Fr. Richard Mngbangun, etc who are engaged in the healing apostolate and exorcising. Ugwu (2014) thus observed that the above scenario is tantamount to syncretic worship which clearly demonstrates that Africans and their religion live on.

Regalia: This is a magnificent dress worn by a person, priest, King indicative of an office such a person holds in society. The ijov/azov spirit possession cult members of the Tiv ethnic denomination of African religion in the Benue valley are found adorned in regalia of different colours during their worship sessions. While the general members may be adorned in white just as members of the choir in Christian churches in Tivland do; the leaders have an option of colours to choose from (Adega 2019:290). The regalia are designed in the fashion of 


\section{Macrothink}

Christian Catholic priests.

The colours could be white, black or red. The colour worn by the leader is indicative of the sect of the cult. Expatiating on the colour symbolism in the regalia, Odili $(2017: 157)$ explained that the regalia and its colour distinguishes one sect from the other and that the colour signifies the status and rank of the members. On the white colour, he maintained that it represents goodness, purity and life in traditional African cultures; whereas red which represents blood or danger which cleanses the members.

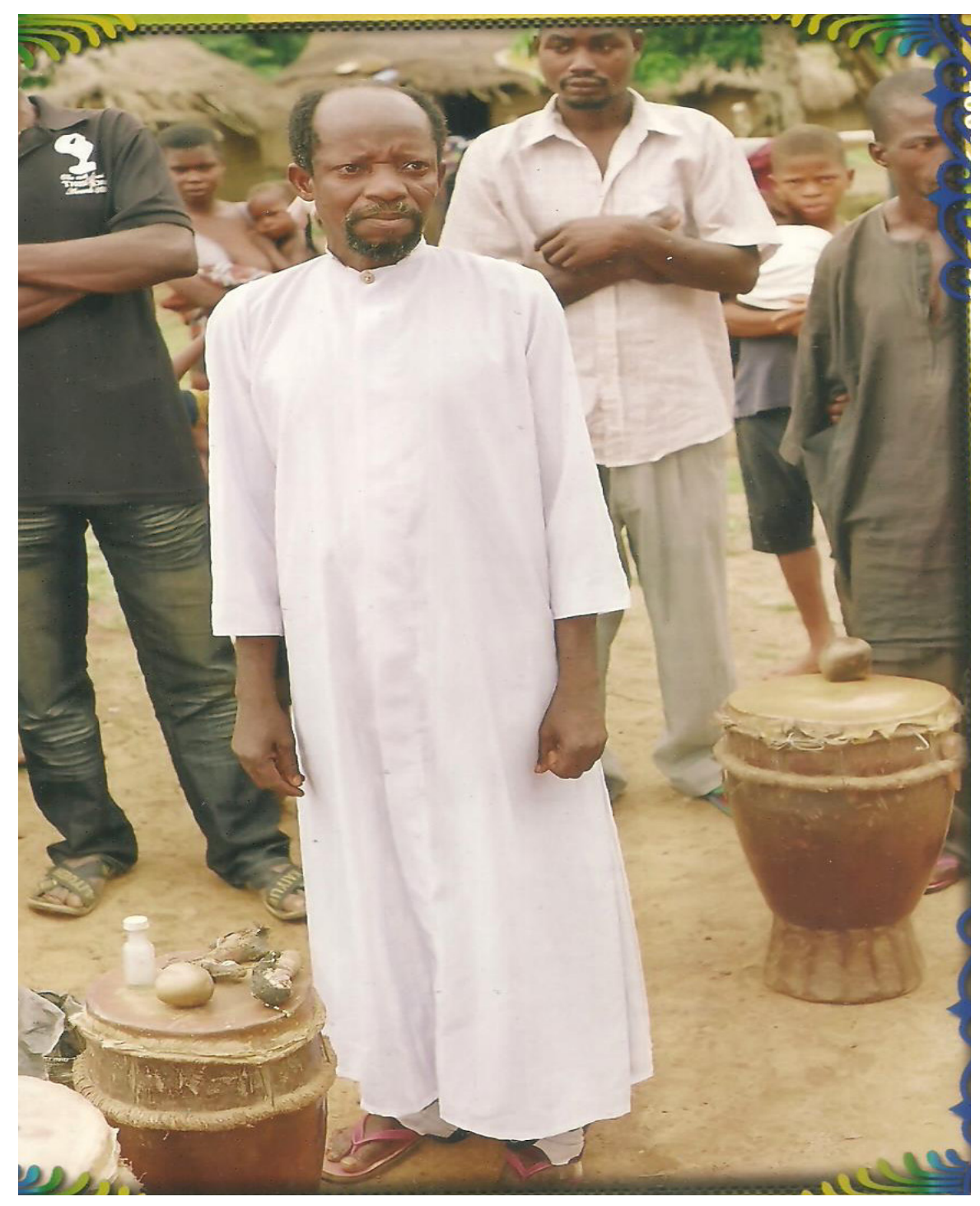

Plate 4. Mr. Angbem Kwashir priest of Ijov Agera Ibel sect at Tse Tyoher, Naka, Gwer West Local Government Area of Benue State poses in his regalia amidst worshippers and drums. The white regalia is designed in the form of a cassock 


\section{MInstitute ${ }_{\text {Mnk }}^{\text {Macrothink }}$}

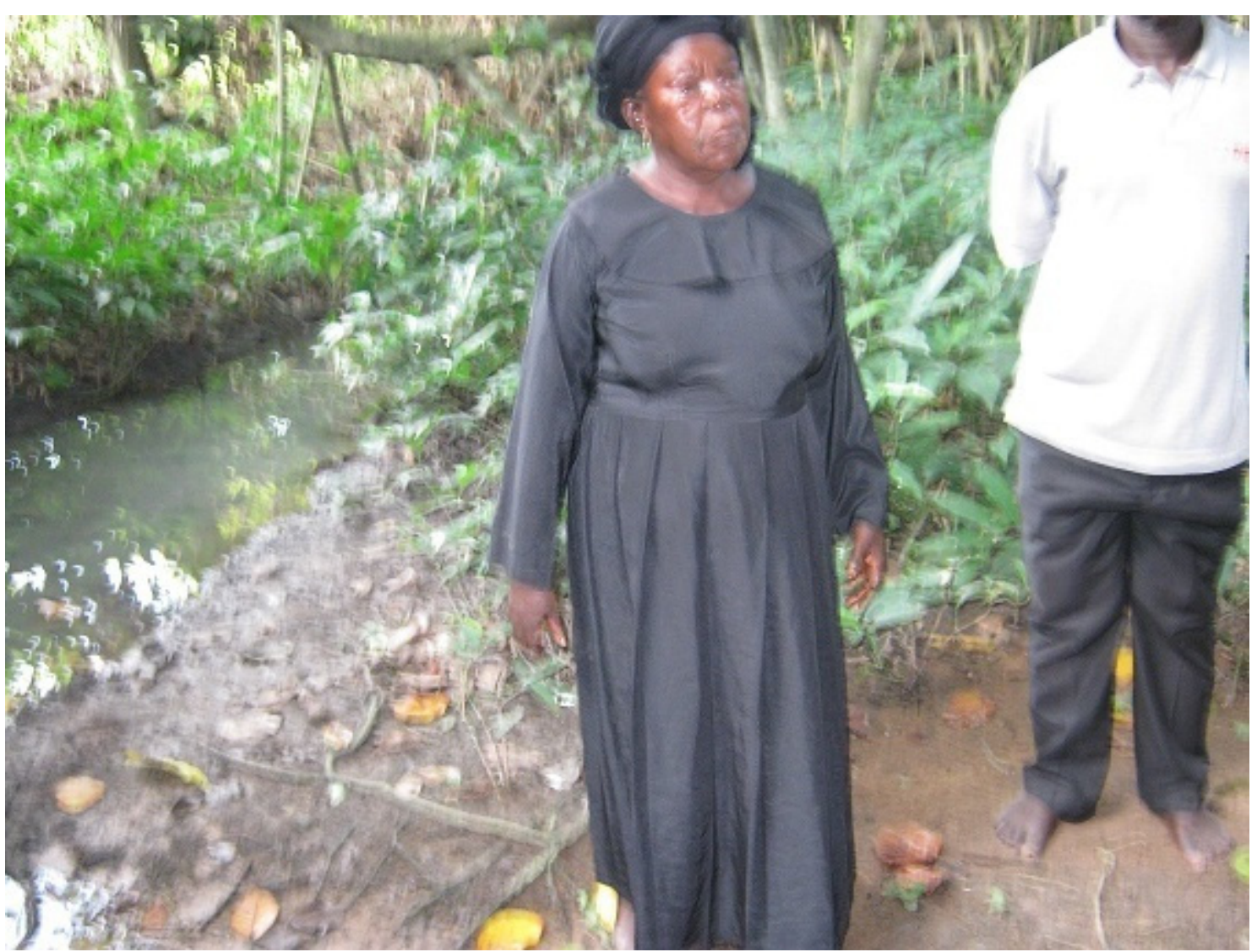

Plate 5. Dondo Iorkaha, a priestess of Ijov Aôndo sect at Nongoatse, Ukum Local Government Area of Benue State pose for a snap shot backing the ityungu I ciin iyol where healing takes place. As a sacred place shoes are not worn within the vicinity of the stream.

Note the black coloured regalia

From the foregone analysis, it becomes difficult and one cannot be certain as to why the Tiv ethnic denomination of African religion have syncretized much from the foreign religions especially Christianity. However, some scholars have given an insight into this phenomenon. In the view of Mokotso (2015:150), African Religion permits syncretism. He anchored his thesis on the ground that African Religion allows a person to practice both Christianity and African Religion both at the same time.

In this perspective, a person is free to be baptized, attend church services/mass, and take part in the sacraments of the church; while still practicing African Religion - nominal Christianity. This seems to suggest that foreign religious rituals from Islam and Christianity which the indigenous religious deem appropriate for their worship can equally be syncretized and adopted. However, for Awolalu and Dopamu (2005:269), the Tiv ethnic denomination of African could well have syncretized many of these patterns of worship, prayer, holy water and other religious objects and rituals from Islam and Christianity because they are believed to contain powers in them which can be used to achieve man's ends.

Yet, some scholars opined that since Africans lost their indigenous religions from the hands 
of the Arabian and western overlords, they were left with only two options namely (a) to embrace the incoming religions, Islam/Christianity. To this, Madu citing Trimingham in a foreword to Nweke (2017: VIII) contended that:

The indigenous religions, being primarily local and ethnic, have no future in their oragnised forms and the religious future of the Africans today lies between Christianity and Islam on the one hand and secularism on the other.

The above scenario could very possible explain the dilemma of African Religion and its adoptive coping strategies of survival and relevance which necessitated the syncretisation of Islam and Christian ritualistic practices to maintain relevance and stay above board.

\subsection{The Impact of Syncretism on the Ethnic Denominations of African Religion in the Lower} Benue Valley

The impact of syncretism on the ethnic denominations of African religion in the Benue valley; the Tiv version cannot be over-emphasised. Also, the fact that when two cultures meet, the dominant culture tends to swallow the weaker culture should not escape the attention of this paper either.

In view of the above, the ethnic denominations of African religion in the Benue valley, particularly Tiv religion stands the risk of being overwhelmed and subsumed into the dominant Christian religion which represents the cultures of Western Europe. Furthermore, syncretizing elements of Islamic and Christian religions would automatically rob the Africans of their culture and identity.

Already, most adherents of the ethnic denominations of African religion in the Benue valley have cross-carpeted in large numbers to Islam and Christianity. This has left only a few committed adherents of the indigenous religions. Thus, if the onslaught on the religion and culture of the ethnic nationalities of Africans in the lower Benue is not curtailed, sooner than later, the whole place would have been infiltrated with foreign ideas, cultures and values.

In the face of globalization and its challenges, this is not the fate that should befall any of the denominations of African religion anywhere. This would if permitted usher in the cultural neo imperialism of the Africans in the $21^{\text {st }}$ century where globally, there has been cultural renaissance and non-Africans have been coming back to Africa to study African cultures.

\subsection{Syncretising Cautiously: The Way Forward}

From the foregone discussion, it has been obvious that syncretism in religious circles cannot be convincingly avoided. Thus, elements from one religion do necessarily stray into another and they are amalgamated and find a permanent place in such an adopting religious tradition. That fact that renowned religious traditions of the world including Christianity and Islam have had to syncretized from Zoroastrianism and Greco-Roman traditions says much on the subject matter under discussion.

Since religious syncretism cannot be completely avoided, the paper calls on the ethnic denominations of African religion in the Benue valley to trade with caution in the embrace of 
syncretism and the adoption of foreign elements into their original practices. This when not handled with tact and caution has the prospect of these indigenous religious traditions losing their originality and identity. This must be avoided in an era of globalization in which the dominant cultures of the west are gradually swallowing up African cultures.

The paper calls for the teaching of African Religion and culture at all the levels of education beginning from the primary- tertiary institutions in Africa and Nigeria in particular. African cultural studies can be introduced in Nigerian Universities as a step in the right direction. As Mokotso (2015:161) puts it, the teaching of African Religion in schools would be a tool for decolonization of the mind of young Africans. According to him, the decolonization process would mean a way to frame a psycho educational approach for cleansing African minds off cultural invasion by designing new-old (African religion - Christianity) structure and install it in African mind.

To the above, courses and subjects which focus on the peoples culture such as Social Studies must be encouraged in at all the levels of education in Nigerian schools. Those saddled with curricular development must dissuade from the practice of phasing out important subjects which deal with national cultures and the people's way of life as is being done presently with primary and secondary school curriculum.

Furthermore, negligence of African Religion automatically translates to disregarding the source of African Indigenous Knowledge System (IKS). This is because, IKS is a knowledge system acquired over generations by communities through their interaction with the environment. IKS is embedded in African traditional beliefs and has been handed down through generations by cultural transmission. It embodies spiritual relationships, religious beliefs in relationship with the natural environment and the use of natural resources, relationships between people and is reflected in a language, social organization, values, institutions and laws. Mokotso (2015:161-162) thus sees the negation of African Religion as a reflection of colonized mind which Africans have been transformed to have negative perception of their culture.

\section{Conclusion}

Syncretism is used to denote any mixture of two or more Religions. For instance, where elements form several religions are merged and influence each other mutually. The principles of religious syncretism hold that when two cultures meet and interact, they will exchange religious ideas with the dominant culture prevailing in the exchange (Gier 1994:1). This is where the ethnic denominations of African Religion in the Benue valley; particularly the Tiv denomination must be careful in syncretizing the Islamic and Christian elements into their original practices.

The tendency is that with time, these ethnic denominations of African religion will lose their original identity, culture and relevance and become obscured. This must not be allowed to happen as it would leave the Africans without a culture or an identity. Thus, the paper concludes in a very positive note as does Ugwu (2014:45) that:

African Religion can never be lost to antiquity or ever submit to the choking, 
suffocating challenges of imported religions - Christianity and Islam and their concomitant snares and delusions that they are regularly seeking scrumptiously for its extinction or demise.

Finally, Joseph M. Murphy observed the term syncretism has become somewhat contested and fallen into some disuse and is often replaced with such terms like religious hybridity and religious creolisation. The term is also typically used on those who are accused of abandoning a historic faith and practice in pursuance of some ecumenical religion which transcends the boundaries of existing religions. John Bowker pointed out that it remains an undeniable fact that most religious traditions of the world if not all are syncretic by nature because they absorb and incorporate elements of other religious traditions and cultures as they encounter them. Therefore, while the syncretism of religion may be a necessary evil; religious traditions absorbing new elements must be cautious not to over assimilate these new ideas to the tune of making their original systems obscured.

\section{References}

Adega, A. P. (2013). Christianity and Indigenous Christian Movements in West Africa. Makurdi: Obeta Printing and Publishing. Print.

Adega, A. P. (2014). Water Conservation and Ritual Performance in African Religion. SWEM: Journal of Religion and Philosophy, 4(1).

Adega, A. P. (2019). An African Perspective on Phenomenology of Religion. Makurdi: Gwatex Publishers.

Awolalu, J. O. (1976). What is African Traditional Religion? Studies in Comparative Religion, 10(2), 1-10.

Awolalu, J. O., \& Dopamu, P. A. (2005). West African Traditional Religion (revised ed.). Ibadan: McMillan.

Ezenweke, E., \& Kanu, I. (2012). Perspectives of Syncretism and its Modern Trend: A Case of Christian and African Traditions. UJA: Unizik Journal of Arts and Humanities, 13(2). https://doi.org/10.4314/ujah.v13i2.4

Gbenda, J. S. (n.d.). African Religion and Christianity in a Changing World: A Comparative Approach. Nsukka: Chuka Educational Publishers.

Gier, N. F. (1994). Religious Syncretism. Retrieved from https://www.webpages.uidaho.edu/ngier/syncretism/html. Accessed 18/10/2020. web.

Higgins, E. (1965). "Water". The Catholic Encyclopedia for School and Home II. New York: Grolier Inc.

John, B. (n.d.). The Concise Oxford Dictionary of World Religions.

Joseph, M. M. (2020). “Syncretism”. Contemporary American Religion.

Kanu, I. A. (2015). A Hermenutic Approach to African Traditional Religion, Theology and 
Philosophy. Jos: Augustinian Publication.

Madu, J. E. (2017). Foreword. In N. Innocent (Ed.), African Traditional Religion in the Midst of Secularism. Onitsha: Spiritan Press.

McDowell, J., \& Gilchrist, J. (1983). The Islam Debate. San Bernardino, California: Here's Life Publishers Inc.

Mokotso, R. I. (2015). Syncretism of Basotho Traditional Religion and Christianity: Gateway to the Syncretistic teaching of Basotho Traditional Religion and Christianity in Lesotho Schools. African Journal of History and Culture, 7(7). https://doi.org/10.5897/AJHC2015.0260

Nyuyki, P. S., \& Van Niekerk, A. (2016). Syncretism and Inculturation in the Nso' Context of Cameroon. Stellenbosch Theological Journal, https://doi.org/10.17570/stj.2016.v2n2.a18

Odili, J. U. (2017). The Use of Symbols in African Christianity. African Symbols and Iconography: A Reader. Port Harcourt: University of Port Harcourt Press.

Okeke, C. O., Ibenwa, C. N., \& Okeke Toochukwu, G. (2017). Conflicts between African Traditional Religion and Christianity in Eastern Nigeria: The Igbo Example. SAGE Open, 1-10. https://doi.org/10.1177/2158244017709322

Sanou, B. (n. d.). Religious Syncretism as a worldwide Mission Challenge: A Biblical and Missiological Response. $A A M M, 8$.

The Oxford Pocket Dictionary of Current English.

Ugwu, C. O. T. (2014). The Demise of the African God/s: Fallacy or Reality. $84^{\text {th }}$ Inaugural Lecture of the University of Nigeria Nsukka. Nsukka: UNNP, $14^{\text {th }}$ August.

\section{Copyrights}

Copyright for this article is retained by the author(s), with first publication rights granted to the journal.

This is an open-access article distributed under the terms and conditions of the Creative Commons Attribution license (http://creativecommons.org/licenses/by/4.0/) 